\title{
Alicja Brodzka
}

Uniwersytet Ekonomiczny we Wrocławiu e-mail: alicja.brodzka@ue.wroc.pl

\section{THE DEADWEIGHT COST OF IMPLEMENTATION OF THE FOREIGN ACCOUNT TAX COMPLIANCE ACT (FATCA)}

\begin{abstract}
Summary: From 1 June 2013 FATCA - the new American law on the disclosure of financial information about foreign accounts for tax purposes - came into force. The aim of the Foreign Account Tax Compliance Act is to prevent the tax evasion of US citizens with offshore accounts. The Act requires all foreign financial institutions to identify American people in possession of the financial accounts (banking, brokerage, etc.), and then transmit that information to the tax authorities of the United States. The penalty for failure to comply with this requirement will be a $30 \%$ withholding tax on capital flows from the United States. The article presents the main issues connected with FATCA and brings closer the arguments pro and contra. As the Act results in new requirements which non-US financial institutions have to fulfil, the paper looks both at the legislative and cost-related problems. It also analyses how the new provisions will influence Polish financial institutions and their customers.
\end{abstract}

Keywords: FATCA, exchange of tax information, international tax law, foreign financial institutions.

DOI: $10.15611 /$ nof.2014.4.01

\section{Introduction}

Unlike many other jurisdictions, US tax liability is attached to citizenship or greencard holder status rather than residence which means, regardless of where US persons reside they are liable to pay tax in the US. In order to increase the ability of the US tax authorities to combat cross-border tax evasion by US persons and improve taxpayers' compliance, in 2010 the US Congress enacted the Foreign Account Tax Compliance Act (FATCA).

FATCA was introduced as a part of the Hiring Incentives to Restore Employment Act, a complex tool designed to stimulate the American economy. The background of such a solution was the financial crisis of 2008-2010 with its effects of growing unemployment and rapidly rising US public debt (which currently exceeds more than 16 trillion USD). The US authorities, in order to counteract the worsening economic 
conditions and stimulate the market, have implemented a number of monetary instruments (such as quantitative easing), macro-economic and fiscal incentives to restore employment (HIRE), and FATCA - an Act introduced directly to target those who evade paying US taxes by hiding assets in undisclosed foreign bank accounts [Strzelecki 2013].

Scheduled to take effect in 2013, FATCA requires that banks and financial institutions - also non-US ones - gather information and disclose it to the US tax collection agency. The penalty for failure to comply with this requirement is quite severe - non-compliant institutions will be "punished" by a $30 \%$ tax on capital flows from the United States.

The FATCA legislation has attracted worldwide criticism, partly because of the compliance costs and partly because it would require financial institutions from other countries to break the law in some jurisdictions. In particular, banks in EU Member States are bound by the EU Data Protection Directive, which includes a general ban on the transmission of sensitive personal information to the USA. Experts have also pointed out that while the US motivation seems to be reasonable, the new legislation will also impose burdensome due-diligence, information reporting and withholding obligations on all foreign (non-US) financial institutions (FFIs).

\section{FATCA requirements for foreign financial institutions}

FATCA affects the whole value chain as it requires completely new and extended information and reporting systems. The new US law is aimed at foreign financial institutions and other financial intermediaries - like banks, stock brokers, hedge funds, pension funds, insurance companies and trusts - to prevent tax evasion by US citizens and residents through the use of offshore accounts. The definition of a foreign financial institution is wide and affects all entities with no registered office in the US that:

1) accept deposits from US citizens;

2) manage financial assets for other entities;

3) or manage investments in securities, goods or trade them on behalf of US citizens [Deloitte 2011].

FATCA requires FFIs to provide annual reports to the Internal Revenue Service (IRS) on the name and address of each US client, as well as the largest account balance in the year and total debits and credits of any account owned by a US person. In addition, FATCA requires any foreign company not listed on a stock exchange or any foreign partnership which has a $10 \%$ US ownership, to report to the IRS the names and tax identification number (TIN) of any US owner.

FATCA also demands that US citizens and green card holders, who have foreign financial assets in excess of 50000 USD, report to the US Internal Revenue Service all foreign financial account assets. Under the scope of this provision fall not only bank accounts, but also securities accounts, annuity contracts, rental properties, 
insurance contracts, pension plans, trusts and private investments in companies and partnerships. This requirement goes in addition to the reporting of foreign financial accounts which is already required by the US Department of the Treasury [ACA 2011, p.7].

For pre-existing accounts held by individuals whose balance is between 50000 USD and 1 million USD, FATCA requires FFIs to search only automated files for US indicia in order to ascertain whether the account refers to a US person or not. Accounts with a balance that exceed 1 million USD must be subjected to a review of their automated and manual files for US indicia. For new individual accounts, the FFIs would be obliged to review the information provided at the opening of the account, including identification and any documentation collected under the "know your customer" rules and anti-money laundering procedure.

With respect to entity accounts, foreign financial institutions are essentially required to focus on passive entities with a view to identifying substantial US owners. For pre-existing accounts, FFIs may rely on information collected under the "know your customer" rules and/or the anti-money laundering procedure or, alternatively, may have to obtain information regarding all substantial US owners (depending on whether the account balance exceeds 1 million USD or not). For new entity accounts, the FFIs are required to determine whether the entity has any substantial US owners upon opening a new account by obtaining a certification from the account holder [Article 29 Data Protection... 2012].

If the foreign financial institution does not comply with FATCA and does not enter into an agreement with the IRS, all relevant US-sourced payments, such as dividends and interest paid by US corporations, will be subject to a $30 \%$ withholding tax. Withholding tax imposed at a rate of $30 \%$ applies to all "withholdable payments" and "passthru payments" received by an FFI. The term "withholdable payments" is defined to mean any payments of interest (including any original issue discount), dividends, rents, salaries, wages, premiums, annuities, compensation, remuneration, emoluments, and other fixed or determinable annual or periodical gains, profits and income, if such a payment is from sources within the United States. Thus, withholdable payments generally include all types of US-source income. Unlike other types of income generally subject to US withholding tax, the term "withholdable payment" also includes any gross proceeds from the sale of property that give rise to dividend or interest income, generally US stocks and US debt instruments. A "passthru payment" is any withholdable payment or any payment attributable to a withholdable payment [Eckl, Sambur 2012, p. 37].

At present, FATCA is an issue for financial institutions, but will also inevitably become an issue for US persons in Poland. Clients maintaining accounts in foreign banks (including Polish ones) will then have to ask the question whether their bank is FATCA-compliant. If not, it will meet the consequences in receiving the US income minimised by the extra $30 \%$ withholding. All individuals and companies receiving a US income will have to consider the potential necessity to either declare 
their residency status in advance or move their assets to another institution that will have the status of FATCA participating FFIs [Deloitte 2011]. As M. Olecki, Senior Manager at Deloitte Financial Institutions Sector says: "If a foreign financial institution does not sign an agreement with the US tax services, it must take into account the $30 \%$ penalty imposed on all eligible transfers from the US - on all transfers and not just on transfers from the citizens of this country. As a consequence, customers who make transfer of funds from the United States should carefully check whether their bank or brokerage office has the relevant agreement on this issue, otherwise they will put themselves at considerable costs" [Deloitte 2012].

\section{The costs of FATCA}

The announcement of FATCA provisions has caused significant controversy and resulted in discussions among politicians and professionals. Supporters raised both the national issues (like protecting the US tax base), and international reasons (like fighting tax evasion and strengthening the transparency of international financial flows). Opponents pointed out that while FATCA's goals of full tax compliance and transparency are justified and worthy, the whole concept of FACTA is an economic nonsense. The Swiss-American Chamber of Commerce Report [Deloitte 2011] gave some numbers concerning the costs and benefits of the new US law. Implementation costs were estimated at 500-1000 billion USD worldwide, while running costs at 10-30 billion USD worldwide. The report compared the costs with the projected benefits of FATCA: additional tax revenues of 8.5 billion USD over 10 years gave a global rate of return of FATCA of $1 \%$. The simple commentary of professionals' environment said: "Ask the world to pay 100 USD for the US to get less than 1 USD” [Swiss-American Chamber of Commerce 2011].

The financial environment quickly pointed out that the expenditure necessary for the adaptation of the global financial system will result in much higher numbers than the tax benefits of FATCA expected by the US tax authorities. The principles of FATCA impact on the process of opening a current account, transaction processing systems and know your client procedures. A detailed plan is necessary to manage all the possible risks resulting from the Act. Foreign financial institutions have to establish and implement a new information flow system or adjust their existing systems in the way which allows providing US tax authorities with all necessary data. Foreign financial institutions have to enter into an arrangement with the US tax authorities regarding the provision of information on account and insurance policy holders being American citizens [Deloitte 2011]. The reporting duties also require the capture and reporting of information that may not now be tracked and accessible. FFIs will be obliged to obtain and store static data on account holders that is not required today.

During the XVIII Conference "IT in financial institutions" which was held in March 2013 in Warsaw, there was a debate about the threats to the financial 
sector posed by the requirements of FATCA. The representatives of major banks operating in Poland and companies providing solutions for financial institutions pointed out that the implementation of the new law will result not only in significant costs, but will also require a number of major organisational changes in financial institutions. IT systems will have to be equipped with additional functions related to the identification and acquisition of information about customers or transactions with US customers. The participants stressed that the implementation of FATCA will incur costs not connected with creating additional value for their customers [Uryniuk 2013]. For participating FFIs, investment will be needed in three key areas:

1. Documentation (capturing process changes and analysing the customer base).

2. Withholding (building functionality for withholding on recalcitrant account holders).

3. Reporting (building and sustaining an annual reporting model for all US individuals to cover account balances and gross payments).

Analyses by tax experts confirm the big financial burden which FFIs will face. The Deloitte Poland Report [Deloitte 2012] estimated that the costs of implementing FATCA in global financial institutions may be as high as 200 million EUR. The biggest Polish banks may have to take into account implementation costs of 15 million EUR. It is worth noting that those FFIs that are able to accept the "Deemed Compliant" status (e.g. the position when the foreign financial institution waives the US customer service completely) could reduce costs even below a million USD. According to Deloitte the majority of the sum will have to be spent within 2-3 years [Deloitte 2012].

The Deloitte experts also point out that the requirements of FATCA will affect most of the institutional and some of the individual clients of Polish financial institutions. The business entities will be required to submit additional documentation confirming American tax status, including additional personal and corporate data. In the case of individuals, the main consequences will apply to the so-called "US Persons" - US citizens who hold dual citizenship or a green card. They will need to, among other things, check out the terms of use for financial products and sign the annexes to the agreements. Thus they will have to agree to report personal and financial data, and to process the information for the purpose of tax identification by the US Internal Revenue Service.

\section{Are foreign financial institutions ready for FATCA?}

FATCA provisions apply to a wide range of foreign financial institutions and impose additional requirements as described in the previous part of the paper. All FFIs are subject to FATCA if they have either US clients or hold US assets in any form. To comply, foreign financial institutions will have to review and leverage the antimoney laundering and "know your customer" procedures, and may have to change the way new customers are approved and documented. In some cases, institutions 
will face updating their IT infrastructures to ensure that they have the tools to withhold tax on applicable payments and report the requisite information to the IRS.

Compliance with FATCA demands financial institutions adopting a crossfunctional approach that incorporates their compliance, operations, tax, legal and information technology departments. In $2012 \mathrm{KPMG}$ conducted a global survey of global and regional banks, insurance companies and various other financial institutions - such as global investment banks and broker/dealers, securities companies and transfer agents - to assess participants' awareness, attitudes and actions regarding FATCA [KPMG 2012]. The survey was conducted between May and August 2012 among 129 executives of financial institutions, both headquartered in the United States (57\%) and in other jurisdictions (43\%). KPMG tax advisers asked questions about the steps which those institutions have taken so far, the resources allocated to the task, the time required to the compliance, and the main challenges connected with the FATCA issue.

Most of the respondents have started to tackle FATCA compliance, focusing their efforts on the most pressing issues, such as the identification of US withholding agents and FFIs, and conducting a detailed inventory of their existing processes and systems. The majority of the reviewed organisations (57\%) say they have completed or are undertaking an impact assessment. Foreign financial institutions, when asked about the timescale, predict different schedules needed to adapt to the new law. Most of them (68\%) anticipate that FATCA implementation will take between 6 and 18 months. The second largest group (23\%) forecast that it will require 18 months or more. Only $9 \%$ of FFIs think implementation will require less than six months.

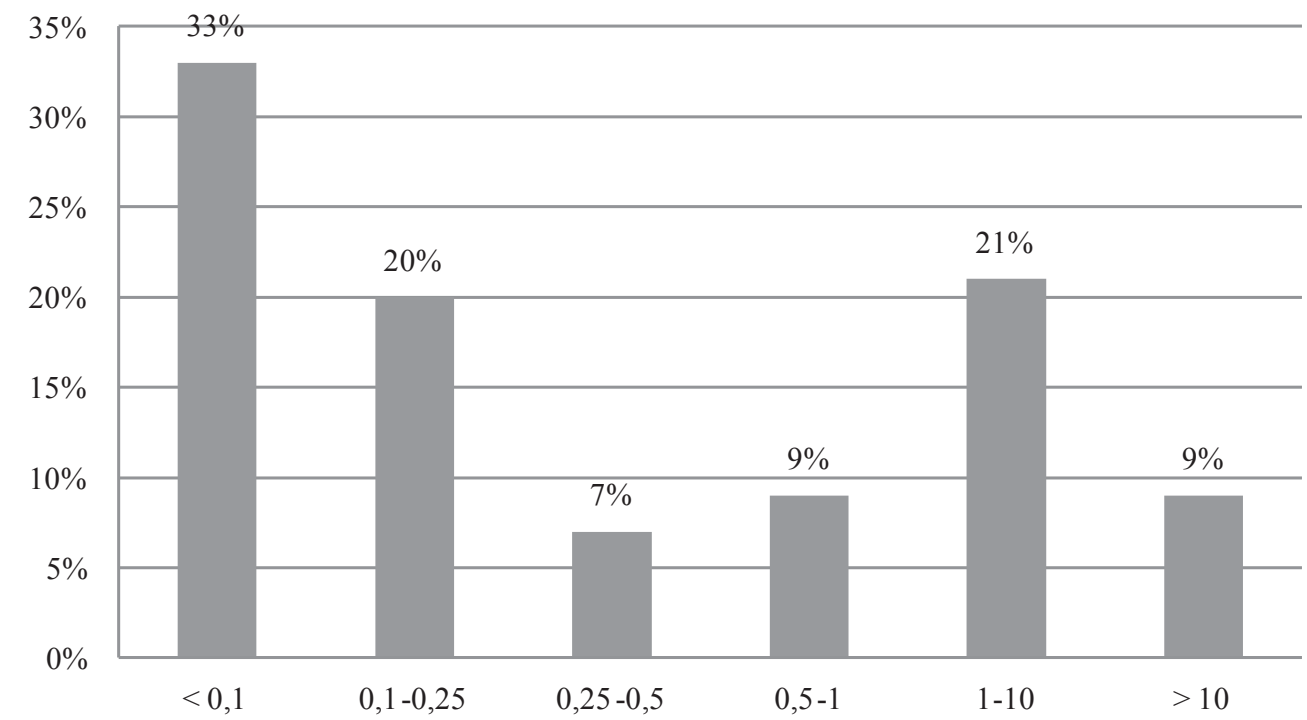

Fig. 1. FFIs costs allocated to FATCA (million USD)

Source: [KPMG 2012]. 


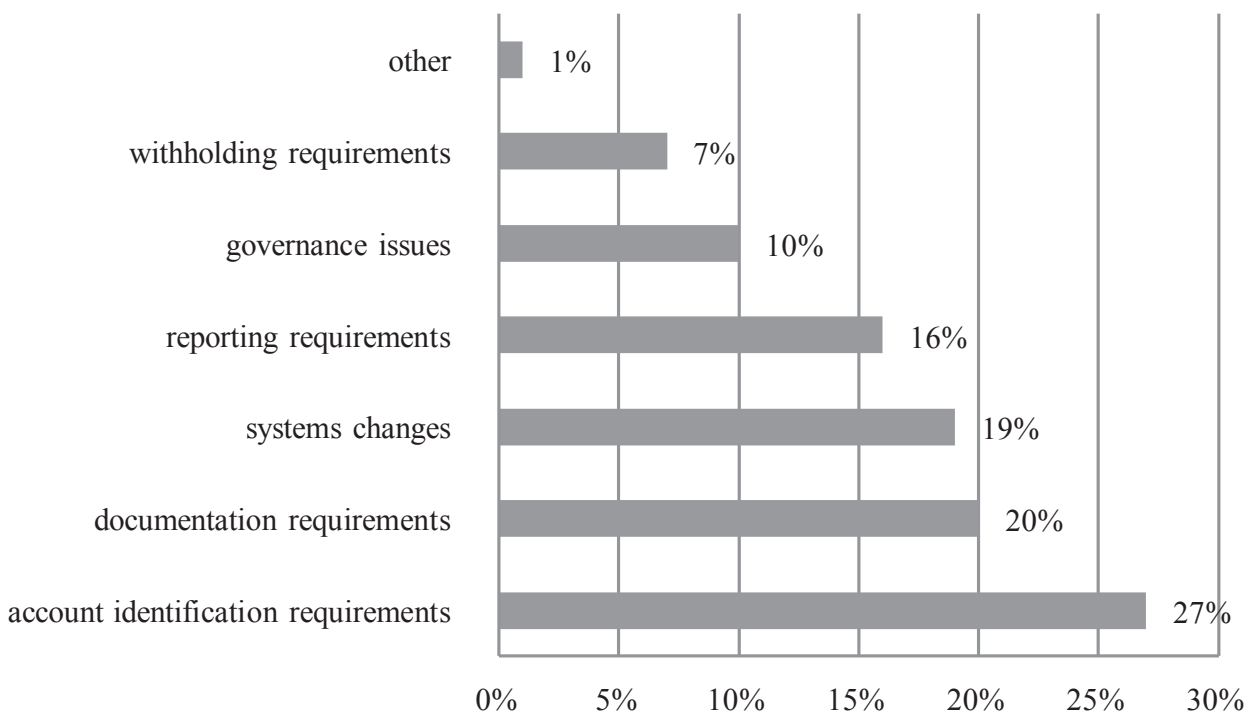

Fig. 2. Biggest challenges for FFIs connected with FATCA

Source: [KPMG 2012].

As for the costs allocated for the implementation of FATCA, median budget allocation was approximately 250,000 USD, although there are wide disparities in the amounts which organisations plan to spend. While more than half of the survey participants (53\%) have allocated or will allocate less than 250,000 USD to FATCA, the second largest single group (21\%) have budgeted for 1 to 10 million USD. At the top end of the scale, a small number of institutions (4\%) earmark 100 million USD or more to their compliance efforts. Detailed costs allocated by foreign financial institutions are presented in Figure 1.

Almost all respondents (92\%) feel that their client on-boarding, customer identification or documentation processes will need to be revised as a result of FATCA. As the main FATCA related compliance challenge foreign financial institutions list: the account identification requirements (27\%), followed by documentation requirements $(20 \%)$, systems changes (19\%), reporting requirements (16\%), governance issues $(10 \%)$ and withholding requirements (7\%). A comparison of biggest challenges which FFIs face with the new American provisions is presented in Figure 2.

\section{Implementation of FATCA}

The FATCA issues have been widely discussed at international level, also at European one. Experts have pointed the problem of the inconsistency of the new American provisions with the EU legislation and the important problem of data protection 
issues. In Poland, Tadeusz Białek, Director of the Legal and Legislative Chamber of the Polish Banks Association, stressed that the collection and transfer of customers' detailed information affect not only national laws on the protection of personal data, but also bank secrecy. Such an opinion was shared also by Wojciech Wiewiórski, Inspector General for Personal Data Protection. He emphasised that the personal and territorial scope of the Act causes a lot of controversy and there are no legal possibilities of using the above mentioned rules in the European Union [Strzelecki 2013].

When working on FATCA provisions, US legislators projected that the American law should be implemented in other countries - unless FFIs want to bear the $30 \%$ withholding tax as a penalty for not complying with US rules. Americans see two options of introducing the law: through individual agreements between international financial institutions and IRS or through intergovernmental agreement. The EU Member States' opinion is different - as FATCA requires from foreign financial institutions reporting obligations that are incompatible with European and national laws, the option of individual FFI-US agreements cannot be accepted. Therefore a measure other than signing individual agreements between FFIs and IRS is needed. Such a solution could be an international agreement. The IRS proposes three types of such consensus:

1. Under the first type of agreement, foreign financial institutions based in a country that has signed the intergovernmental agreement, will not have to sign the additional agreement with the US tax authorities (they will register with the IRS, not enter into an FFI agreement). FFIs will provide the required information to the national tax office, which next will forward it to the IRS on the basis of an intergovernmental agreement. On a reciprocal basis, US banks will be required to provide the same information to the IRS, which in turn will forward them to the tax authorities of those countries which have concluded such international agreements. The agreement of the first type, involving the reciprocity of US institutions, caused an intense discussion in the United States. It would force US banks to bear the costs similar to those which FFIs will have to pay in order to cope with the requirements of FATCA. Nevertheless, from the perspective of third countries, the reciprocity and perspectives of creating an effective system of exchanging the information is the only reasonable motive to accept the requirements of US law.

2. The second type of agreement would operate in the same way, but without reciprocity on the part of the United States relative to other countries. No country has officially decided to accept such a solution.

3. Agreement of the third type would authorise the FFI to send information directly to the IRS without violating the national laws of their country. It is very doubtful if such an agreement would be acceptable for the Member States of the European Union. It does not look like any of the EU Member States agree with such a proposal [Święcicki 2013]. 
In 2012, after complaints from the global financial industry about costs and legal issues, the US Treasury announced a new multilateral approach to implementing the Foreign Account Tax Compliance Act. The Treasury's proposed "new governmentto-government framework" would allow creating the means to collect the information from FFIs and to send the data to the United States without the necessity to enter into separate data disclosure agreements with the IRS. The US Treasury said it would allow foreign financial institutions to rely on information that they have already collected under anti-money laundering and "know your customer" rules to determine whether they have US taxpayers as clients and thus must collect and disclose information about them under FATCA [Browning 2012].

The European Union welcomed the US' acceptance of the government-togovernment approach to implementing FATCA provisions. The intergovernmental approach to tax information exchange was recognised as a good solution allowing for a significant reduction of the administrative burdens, compliance costs and legal difficulties which EU financial institutions would otherwise face in applying the FATCA provisions [The European Commission 2012].

In the meantime some of the Member States started to negotiate with the US on the possibility of implementing the intergovernmental approach. In February 2012 the governments of Germany, France, Spain, Italy and the UK agreed to collect clients' account information from the financial institutions located in their territories and then pass it on to the US tax authorities on behalf of the FFIs. They may also have to amend their own data protection laws. FFIs in these five countries which have agreed to check for American beneficial ownership of assets and to supply this information to their tax authorities will be treated by the US as "compliant with FATCA". They will not have to sign an agreement with the IRS (although they will have to register with it) and they will not be subject to the $30 \%$ withholding tax imposed by the IRS on non-FATCA-compliant banks. Nor will they be required to block payments to "reluctant" individuals, or collect US withholding taxes from other banks in the jurisdiction.

By entering into the intergovernmental agreement, the US has committed itself to collect the information on US bank accounts operated by European residents and automatically pass it on to the relevant national tax authority of the country which concluded the agreement. This reciprocity arrangement would be based on the countries' existing bilateral tax treaties [Europe's big five...2013].

The US Treasury Department has developed an alternative intergovernmental approach to achieving the policy goals of FATCA, while addressing the impediments to FATCA compliance under the laws of other countries, and enhancing general intergovernmental information exchange. Also the FATCA timeline has been modified [PwC 2013]. New key dates which were proposed on 17 January 2013 in the FATCA Final Regulations, are presented in Table 1. 
Table 1. FATCA timeline

\begin{tabular}{|l|l|}
\hline \multicolumn{1}{|c|}{ Year } & \multicolumn{1}{c|}{ FATCA key dates } \\
\hline 2013 & $\begin{array}{l}\text { July 15: the start of FFIs' registration with IRS; } \\
\text { October 25: the last date to register with IRS to ensure inclusion of FFI list; } \\
\text { December 31: the effective date of FFI Agreements if entered into by December 31. }\end{array}$ \\
\hline 2014 & $\begin{array}{l}\text { January 1: the start of the requirement to implement new account on-boarding procedures for } \\
\text { U.S. Withholding Agents, Participating FFIs, and Registered Deemed-Compliant FFIs; } \\
\text { January 1: the beginning date for FATCA withholding on Fixed, Determinable, Annual, Periodi- } \\
\text { cal (FDAP) income payments to non-participating FFIs, non-compliant NFFEs, and recalcitrant } \\
\text { account holders; } \\
\text { January 1: the last date for obligations to be outstanding to qualify as grandfathered obligations } \\
\text { and exempt from FATCA withholding (but still subject to reporting); } \\
\text { June 30: the date for U.S. Withholding Agents, Participating FFIs, and Registered Deemed- } \\
\text { Compliant FFIs to document pre-existing entity accounts identified as Prima Facie FFIs (If the } \\
\text { FFI signed an agreement after 1 January 2014, the deadline is six months from the effective } \\
\text { date of the FFI agreement); } \\
\text { December 31: the date for participating FFIs to document pre-existing high value individual } \\
\text { accounts. }\end{array}$ \\
\hline 2015 & \begin{tabular}{l} 
January 1: reporting deadline for 2013 and 2014 per the final regulations. \\
\hline 2017
\end{tabular}
\end{tabular}

Source: [PwC 2013].

\section{Conclusions}

The Foreign Account Tax Compliance Act as an internal US regulation has no binding force in Poland, at least from a formal point of view. However, due to the FATCA mechanism, the new Act forces its application to those foreign financial institutions that do not wish to find themselves on the margins of the global financial market. Therefore, the implementation of FATCA by financial institutions may result in a number of conflicts with the Polish legal system [Tyszka, Bosak 2012, p.7]. To determine whether the client (both new and existing) is a person from the US, the financial institution will need to gather the data that exceeds the customers' information collected on the basis and within the limits of Polish law. It seems that looking at the Law on Personal Data Protection, as well as at the rules relating to the professional secrecy in various sectors of the financial market, there is no legal basis for such action.

For the "FATCA problem" the most appropriate solution seems to be an agreement with the US signed at EU level. At present there is a discussion going on, whether the introduction of FATCA provisions is possible in the European Community and on what terms - and it does not look like a consensus can be reached in a nearest future. However, in solving the problem of additional rules becoming slowly the reality for the financial environment, Poland can use the experience of other EU Member States. In conclusion, the agreements by the governments of France, Germany, Italy, the UK and Spain can be a good example to follow. Based on these 
intergovernmental agreements, the appropriate changes in the national legal system can be made to allow for the collection and the transfer to the United States all the information required by FATCA.

Polish authorities could negotiate and conclude a bilateral agreement with the US using the intergovernmental approach worked out by the United States and five European countries. Moreover, Polish institutions such as the Ministry of Finance, the Financial Supervision Authority and the Inspector General for the Protection of Personal Data, should develop legislative proposals regarding the implementation of FATCA provisions by the Polish financial institutions, in order to avoid any future conflicts with Polish law.

In the wider perspective, the forthcoming US Foreign Account Tax Compliance Act could have wide-ranging implications for global structured finance transactions. Although the Act is not intended to be retrospective, and as such it is not expected to result in widespread negative rating actions, the breadth of the Act and its complex practical implications mean that there could be possible cash-flow disruptions and rating implications in individual transactions. Fitch Ratings points at the need of monitoring developments and expects that global structured finance transactions and counterparties will address any uncertainties [Fitch 2012].

Some financial institutions also mentioned the possible advantages which the new American Act can bring to the global financial environment. As FATCA influences the entire organisation, achieving compliance will require the review and assessment of every legal entity and business unit within the institution. While this scrutiny brings significant challenges, approached the right way the work involved can also uncover various opportunities, such as ways to streamline the whole organisational structure, enhance processing efficiencies or realign the business model.

\section{References}

ACA, 2011, Why FATCA is Bad for America and Why it Should be Repealed Now!, ACA Report, July. Article 29 Data Protection Working Party, 2012, A letter to the Director General of Taxation and Customs Union” Brussels, 21.06.2012, Ref. Ares (2012)746461.

Browning L., 2012, US enlists 5 EU nations in offshore tax crackdown, Reuters, 8.02.2012.

Deloitte, 2011, FATCA (Foreign Account Tax Compliance Act) - The new law introduced in the U.S. shall impact Polish companies and natural persons, receiving US sourced income, Deloitte Poland.

Deloitte, 2012, FATCA - polskie instytucje finansowe czekaja duże wydatki, Deloitte Press Releases, 12.06.2012.

Eckl P., Sambur J., 2012, The Impact of the US Foreign Account Tax Compliance Act (FATCA) on European Entities, European Taxation, IBFD, January.

Europe's big five will help USA enforce FATCA, Stepjournal.org, 9.02.2012 (1.05.2013).

Fitch, 2012, Wide Reach of FATCA May Impact Global SF Cashflows, FITCH Ratings - Press Releases, 30.08.2012.

KPMG, 2012, Surveying the market: Are you ready for FATCA?, KPMG International, December. 
PwC, 2013, FATCA Regulatory Timelines, PwC, 12.02.2013.

Strzelecki J., 2013, FATCA coraz blizej, „Gazeta Bankowa”, 1.04.2013.

Swiss-American Chamber of Commerce, 2011, Some thoughts on FATCA, Swiss-American Chamber of Commerce, 25.07.2011.

Święcicki P., 2013, FATCA grozi wzrostem bankowych kosztów, „Parkiet”, 5.01.2013.

The European Commission, 2012, The US Foreign Account Tax Compliance Act (FATCA) - State of Play, European Commission Working Document, Brussels, 6.02.2012.

Tyszka S., Bosak K., 2012, FATCA i jej konsekwencje dla polskich instytucji finansowych, Centrum Analiz Fundacji Republikańskiej, September.

Uryniuk J., 2013, Bankowcy chca technologii, ale boją się nowego ryzyka, „Dziennik Gazeta Prawna”, 18.03.2013.

\section{KOSZTY IMPLEMENTACJI FATCA}

Streszczenie: 1 czerwca 2013 r. weszła w życie FATCA - amerykańska ustawa dotycząca ujawniania informacji finansowych o zagranicznych rachunkach w celach podatkowych. Zadaniem nowej regulacji jest zapobieganie unikania opodatkowania przez amerykańskich podatników posługujących się kontami offshore. FATCA zakłada nałożenie dodatkowych obowiązków na banki i inne instytucje finansowe nieposiadające siedziby w USA. Instytucje te zostały zobowiązane do zbierania informacji o klientach amerykańskich posiadających zagraniczne konta, a także do późniejszego raportowania zgromadzonych danych do amerykańskiego urzędu skarbowego. W przypadku niewywiązywania się przez instytucję finansową z obowiązków informacyjnych narzucanych przez FATCA przepływy kapitału ze Stanów Zjednoczonych mają być obciążane 30-procentowym podatkiem u źródła. Artykuł prezentuje główne zagadnienia związane z FATCA, argumenty za i przeciw, a także przedstawia problemy kosztowe i prawne dotyczące wprowadzenia nowej regulacji. Bada również wpływ nowej ustawy amerykańskiej na polskie instytucje finansowe i ich klientów.

Słowa kluczowe: FATCA, wymiana informacji podatkowych, międzynarodowe prawo podatkowe, zagraniczne instytucje finansowe. 